\title{
SELECTION AND CHARACTERIZATION OF CAROTENOID-PRODUCING YEASTS FROM CAMPINAS REGION, BRAZIL
}

\author{
Iriani R. Maldonade*; Adilma R. P. Scamparini; Délia B. Rodriguez-Amaya \\ Universidade Estadual de Campinas-UNICAMP, Faculdade de Engenharia de Alimentos, Departamento de Ciência de \\ Alimentos, São Paulo, Brazil
}

Submitted: February 20, 2006; Returned to authors for corrections: April 27, 2006; Approved: October 13, 2006

\begin{abstract}
The objective of the present study was to select and identify yeasts from Brazil capable of producing carotenoids. Pigmented yeasts were isolated from soil, leaves, fruits, flowers and a processed product. The samples were incubated at $30^{\circ} \mathrm{C}$ in Erlenmeyer flasks, containing YM broth. After 48 hours, they were inoculated in Petri dishes with YM agar, and incubated at $30^{\circ} \mathrm{C}$ during 120 hours. The yeast colonies, which presented yellow to red coloration, were transferred to culture tubes containing YM agar, and incubated at $30^{\circ} \mathrm{C}$ for 72 hours. Out of 242 samples, only five had yellow to red color at high intensity. These highly pigmented yeasts were re-isolated in Petri dishes with YM agar and then transferred to tubes with GPYM agar. Identification through morphological and reproduction characteristics, along with physiological and biochemical tests, classified four strains as $R$. mucilaginosa and one strain as $R$. graminis. The main carotenoids extracted from them were identified through HPLC analysis as $\beta$-carotene and torulene. The strains showed potential as promising microorganisms for the commercial production of carotenoids.
\end{abstract}

Key words: pigmented yeasts, identification, Rhodotorula, carotenoid, fermentation

\section{INTRODUCTION}

Carotenoids are natural pigments responsible for the pleasing yellow, orange and red color of many foods, e.g. fruits, vegetables, egg yolk, some fish like salmon and trout, and crustaceans. Aside from being natural pigments, carotenoids also have important biological activities. It is well known that some carotenoids are precursors of vitamin A. In more recent years, vitamin A-active and inactive carotenoids have been found to have other beneficial effects on human health: enhancement of the immune system and reduction of the risk for degenerative diseases such as cancer, cardiovascular diseases, macular degeneration and cataract $(2,4,9)$. Thus, carotenoids constitute one of the most valuable class of compounds for industrial applications, e.g. in the pharmaceutical, chemical, food and feed industries.

Color is an important attribute that determines consumers' acceptance of foods. The addition of coloring agents in processed foods has been a common practice for many years. Due to the possible toxicity of artificial coloring agents, natural coloring alternatives have been increasingly sought. The huge international market for carotenoids has been met mainly by synthetic carotenoids with structures identical to those of natural carotenoids, but there is growing demand for natural sources. Traditionally, carotenoids have been marketed as dried powder or extracts from plants, such as annatto, paprika and saffron. Natural colorants from plant sources, however, suffer from a diminishing or unstable supply of raw materials, subject to climatic conditions, as well as varying colorant level and quality of the final product.

Microbial carotenoids have attracted much attention in recent years $(7,12)$. The main reason for the interest in using microorganisms to produce compounds that can otherwise be isolated from plants and animals or synthesized is the ease of increasing production by environmental and genetic manipulation. The commercial utilization of microorganisms with

*Corresponding Author. Mailing address: Faculdade de Engenharia de Alimentos-UNICAMP. Departamento de Ciência de Alimentos, C.P. 6181. Cep: 13083-862, Campinas - SP, Brazil. E-mail: iriani@hotmail.com 
biotechnological potential to produce carotenoids is presently limited by the high cost of production. However, the cost of carotenoid production by fermentation can be minimized by optimizing its process, using highly pigment-producing microorganisms cultured in cheap industrial by-products as nutrient sources (1).

$\beta$-Carotene from the microalga Dunaliella salina is being produced and commercialized by Australia, Israel and the United States. Recently, astaxanthin has also been produced commercially in the United States by another microalga, Haematococcus pluvialis (6). Other microorganisms, however, have the capacity to produce carotenoids, such as the red yeasts of the genera Rhodotorula, Rhodosporidium, Sporobolomyces. The carotenoid compositions are similar, consisting of $\beta$ carotene, $\gamma$-carotene, torulene and torulahodin (18). Torulene is a typical carotenoid found in yeasts. It is a very interesting carotenoid due to its structure, half $\beta$-carotene and half lycopene, which is responsible for provitamin A acivity and antioxidant property.

Brazil has a diverse and unique ecosystem that can provide yeasts with biotechnological potential for the production of carotenoids. The present project was aimed at finding and identifying yeasts from the Brazilian environment, capable of producing carotenoids of possible commercial importance, especially torulene. Yeasts are classified and identified through morphological and physiological characteristics. For a more specific identification, biochemical and nutritional requirements are more accurate than morphological and sexual trait studies.

\section{MATERIALS AND METHODS}

\section{Screening of pigmented yeasts}

Samples were collected from soil, leaves, fruits, flowers and from a processed food as a contaminant. The collected samples were stored in aseptic packing until the analyses commenced. After isolating those strains that presented the desired coloration, the cultures were codified to facilitate future identification. Out of 242 samples collected, only five had a yellow to red color at high intensity. These samples were codified as follows: L12, isolated as a contaminant in tomato puree; L108, isolated from soil of Campinas-SP; L125 isolated from sugar cane leaves; L135 and L137 isolated from soil of Holambra-SP.

\section{Isolation and selection of yeasts}

The samples were placed in Erlenmeyer flasks containing 20 $\mathrm{mL}$ of YM broth $(0.3 \%$ yeast extract, $0.3 \%$ malt extract, $0.5 \%$ peptone and $1.0 \%$ glucose), and incubated at $30^{\circ} \mathrm{C}$ for 48 hours. The samples were then inoculated in Petri dishes containing YM agar and incubated at $30^{\circ} \mathrm{C}$ for 120 hours. Yellow to red colonies were transferred to inclined test tubes with YM agar and incubated at $30^{\circ} \mathrm{C}$ until satisfactory growth. These colored cultures were re-isolated in Petri dishes containing YM agar (incubated at $30^{\circ} \mathrm{C}$ for 72 hours) and transferred to inclined test tubes with GPYM agar (2.0\% glucose, $0.5 \%$ yeast extract, $0.3 \%$ malt, $0.5 \%$ peptone, $0.2 \%$ monobasic sodium phosphate, $2.0 \%$ agar). After this stage, the purity of the strains was verified by microscopic examination. The selected cultures were transferred to agar slope tubes containing the GPYM agar and, after growth, stored at $4^{\circ} \mathrm{C}$.

\section{Morphological characterization}

Classification of the yeasts was based on vegetative and sexual reproductive characteristics, along with physiological and biochemical tests, according to Lodder (11), Kreger-Van Rij (8) and Barnett et al. (3). Identification was based on the comparative analysis of distinguishing morphological, physiological and metabolic characteristics of the strains studied, the results being compared with the data of reference yeast species described in the literature $(3,10,20)$. For these tests, the inoculum of the cultures was grown in GPY-Sabouraud agar $(2.0 \%$ glucose, $0.5 \%$ yeast extract, $0.2 \%$ monobasic sodium phosphate, $1.0 \%$ neopeptone) for $24-48$ hours at $27^{\circ} \mathrm{C}$; then transferred to test tubes with YNB (Yeast Nitrogen Base, Difco) and incubated for 5 days at $27^{\circ} \mathrm{C}$; with daily agitation to deplete nutritional reserves.

Morphological characteristics of the cultures such as shape, cellular dimension and type of cell division were observed by microscopic analysis of the strains grown in a liquid GPY medium (2.0\% glucose, $0.5 \%$ yeast extract, $0.5 \%$ peptone, $0.2 \%$ monobasic sodium phosphate) at $27^{\circ} \mathrm{C}$ for 24 hours. Formation of ring, film and sediment was observed after 7, 14 and 21 days.

Formation of pseudohyphae and mycelium was observed through the inoculation of the yeasts in Petri dishes containing CMA(Corn Meal Agar - Difco), the cultures being covered with a glass slide. The dishes were incubated at $27^{\circ} \mathrm{C}$ and examined microscopically after the 5 to 7 days of incubation.

The formation of ballistospores was verified using an inoculated dish inverted over another Petri dish containing a rich medium (GPY-Sabouraud agar). The two dishes were taped together. The dishes were incubated at $27^{\circ} \mathrm{C}$ for 3 weeks, with CMA medium in the upper part so that, in the presence of balistospores, these spores could be liberated and sprayed in the medium, to be observed macroscopically and microscopically. The sexual reproduction characteristics were observed by microscopic examination of the strains grown in the Petri dishes with the isolation medium (GPYM).

\section{Physiological and biochemical characterization}

After the determination of the main morphologic characteristics of the selected strains, tests were carried out to verify the principal physiological and biochemical characteristics. The ability to metabolize different types of carbohydrate was verified. The assays were carried out in 
inverted Durham tubes containing $2 \mathrm{~mL}$ of basal medium $(0.45 \%$ yeast extract, $0.75 \%$ peptone and blue bromothymol solution) and $1 \mathrm{~mL}$ of the carbohydrate solution being studied. The tubes were inoculated with $0.1 \mathrm{~mL}$ of a dense cellular suspension of cultures grown in GPY-sabouraud agar and incubated at $27^{\circ} \mathrm{C}$ during 24 hours.

\section{Fermentation of carbohydrate}

Assimilation of carbon compounds was verified with hexoses, disaccharides, trisaccharides, polysaccharides, pentoses, alcohols, organic acids and glycosides. These carbon sources were used at a final concentration of $0.5 \%$, in Petri dishes containing YNB agar. The cultures were incubated at $27^{\circ} \mathrm{C}$.

\section{Nitrogen assimilation}

Assimilation of nitrogen compounds (potassium nitrate, sodium nitrite, L-lysine and ethylamine) was tested in Petri dishes with YCB agar (Yeast Carbon Base, without nitrogen source, Difco). The cultures were kept at $27^{\circ} \mathrm{C}$ until satisfactory growth.

\section{Growth at different temperatures}

Growth at different temperatures was investigated in test tubes containing GPY sabouraud, which were incubated in a water bath at 20,37 and $40^{\circ} \mathrm{C}$ for 48 hours.

\section{Growth in vitamin free medium}

Growth in the absence of vitamins was verified in the strains grown in Petri dishes with VFB (Vitamin Free Base), incubated at $27^{\circ} \mathrm{C}$ for 48 hours.

\section{Acid production from the glucose}

The production of acid from glucose was observed in cultures inoculated in media containing $\mathrm{CaCO}_{3}$ agar $(0.5 \%$ yeast extract, $5.0 \%$ glucose, $0.5 \%$ calcium carbonate and $2.0 \%$ agar). Incubation was at $27^{\circ} \mathrm{C}$ per seven days.

\section{Amyloid composite synthesis}

The dishes used in the assays of carbon compound assimilation were also used to verify the synthesis of amyloid compounds. These dishes were covered with lugol for a few minutes after 21 days of incubation. If the color of the colony turned blue, the test was positive.

\section{Cycloheximide test}

The cycloheximide resistance was tested by inoculating the test tubes containing a 10 -fold concentrated basal medium and incubating at $27^{\circ} \mathrm{C}$ for three weeks. This test was prepared by dissolving either $0.1 \mathrm{~g}$ or $1.0 \mathrm{~g}$ of cycloheximide in $2 \mathrm{~mL}$ of acetone, which was added to a solution of YNB medium and glucose $(10.0 \%)$. After thorough mixing, the combined solution was sterilized.

\section{Urea hydrolysis and $D B B$ in these tests}

Coloration of DBB (diazonium blue B) and the urea hydrolysis test were done simultaneously after the cultures had been cultivated in GYP sabouraud agar medium. For the urease test, the cultures were inoculated in tubes containing YCB-urea agar (1.17\% YCB, $0.02 \%$ fucsin acid, $2.0 \%$ agar and $2.0 \%$ urea) and incubated at $37^{\circ} \mathrm{C}$ for 72 hours. The tubes were examined every hour for a change of color to red, indicating urease activity. For the DBB test, the cultures were held at $55^{\circ} \mathrm{C}$ for several hours and flooded with ice-cold DBB reagent.

\section{Activity of the arbutine}

To verify the ability of the yeasts to split arbutin, the strains incubated in GPY sabouraud agar were transferred to arbutin agar $(0.5 \%$ arbutin, $0.5 \%$ yeast extract, $2.0 \%$ agar and $1 \mathrm{~mL}$ of ferric ammonia citrate solution). After incubation at $27^{\circ} \mathrm{C}$ for 5 to 7 days, the color of the culture medium was verified. A change of color from white to dark brown indicated a positive result.

\section{Carotenoid analysis}

Each starter culture was prepared by inoculating one loop of a slant culture in $50 \mathrm{~mL}$ of YM broth (Difco) in a $150 \mathrm{~mL}$ Erlenmeyer flask, incubating at $25^{\circ} \mathrm{C}$ in a shaker at $200 \mathrm{rpm}$ for $72 \mathrm{~h}$. Fermentation experiments were carried out in $500 \mathrm{~mL}$ Erlenmeyer flasks containing $200 \mathrm{~mL}$ of YM broth. Each flask was inoculated with starter culture $(5 \% \mathrm{v} / \mathrm{v})$ and incubated at $25^{\circ} \mathrm{C}$ for 5 days at $200 \mathrm{rpm}$ without illumination. After cultivation, the cells were harvested by centrifugation at 16,000 $\mathrm{x} g$ for 20 minutes, washed twice with deionized water and centrifuged again. The pigments were extracted and quantified according to Rodriguez-Amaya (16). The total carotenoid was determined spectrophotometrically, and expressed as tourelene (R. mucilaginosa) and $\beta$-carotene ( $R$. graminis). For high performance liquid chromatography (HPLC), the extract was concentrated in a rotary evaporator, dried under nitrogen, and redissolved in $1 \mathrm{ml}$ acetone with the aid of sonication. An aliquot of $10 \mu \mathrm{l}$ was then injected into the liquid chromatograph. A Varian liquid chromatograph, model 9010 (Varian Inc., Palo Alto, CA, USA), equipped with a UV-visible photodiode detector, model 994 (Waters Corporation, Milford, MA, USA), was used. The column was Vydac 218 TP54, C18, $5 \mu \mathrm{m}, 4.6 \mathrm{~mm}$ x $250 \mathrm{~mm}$. The mobile phase for Rhodotorula sp strains was tetrahydrofuran: $\mathrm{H}_{2} \mathrm{O}$ :methanol from 15:4:81 to 30:0:70 in a linear gradient in 40min, maintaining this proportion until the end of the run. The flow rate was $0.5 \mathrm{ml} / \mathrm{min}$.

\section{RESULTS AND DISCUSSION}

The results of the morphological and physiological tests and biochemical reactions of the five isolated yeast cultures are presented in Table 1. The five cultures were all classified as Rhodotorula strains. The production of spores was not observed 
Table 1. Morphological, physiological and biochemical results for the pigmented yeast strains.

\begin{tabular}{|c|c|c|c|c|c|}
\hline \multirow{2}{*}{$\begin{array}{c}\text { Culture } \\
\text { Test }\end{array}$} & \multicolumn{4}{|c|}{$\begin{array}{l}\text { Rhodotorula } \\
\text { mucilaginosa }\end{array}$} & \multirow{2}{*}{$\begin{array}{c}\begin{array}{c}\text { Rhodotorula } \\
\text { graminis }\end{array} \\
\text { L125 }\end{array}$} \\
\hline & L12 & L108 & L135 & L137 & \\
\hline $\begin{array}{l}\text { Color } \\
\text { Shape }\end{array}$ & $\begin{array}{l}\text { Red } \\
\text { Circular }\end{array}$ & $\begin{array}{c}\text { Red } \\
\text { Circular }\end{array}$ & $\begin{array}{c}\text { Red } \\
\text { Circular }\end{array}$ & $\begin{array}{c}\text { Red } \\
\text { Circular }\end{array}$ & $\begin{array}{l}\text { Red } \\
\text { Circular }\end{array}$ \\
\hline Ascopore & - & - & - & - & - \\
\hline Conjugation & - & - & - & - & - \\
\hline Pseudohyfae & - & - & - & - & - \\
\hline Mycelium & - & - & - & - & - \\
\hline Ballistospore & - & - & - & - & - \\
\hline Urease & + & + & + & + & + \\
\hline DBB (diazonium blue B) & ) + & + & + & + & + \\
\hline Glucose $50 \%$ & - & - & - & - & - \\
\hline $20^{\circ} \mathrm{C}$ & + & + & + & + & + \\
\hline $35^{\circ} \mathrm{C}$ & + & + & + & + & + \\
\hline $37^{\circ} \mathrm{C}$ & + & + & + & + & - \\
\hline Glucose Fermentation & - & - & - & - & - \\
\hline Starch synthesis & - & - & - & - & - \\
\hline D-glucose & + & + & + & + & + \\
\hline D-galactose & + & + & + & + & + \\
\hline Lactose & - & - & - & - & - \\
\hline Sucrose & + & + & + & + & + \\
\hline Maltose & + & + & + & + & - \\
\hline Cellobiose & - & - & - & - & - \\
\hline$\alpha$-m-D-Glucosideo & - & - & - & - & - \\
\hline D-xylose & + & + & + & + & + \\
\hline Arabinose & - & - & - & - & + \\
\hline$\alpha-\alpha^{\prime}$-Trehalose & - & - & + & + & + \\
\hline Melezitose & + & + & + & + & - \\
\hline Raffinose & + & + & + & + & + \\
\hline N-Acetyl-Glucosamine & - & - & - & - & - \\
\hline Xylitol & + & - & - & + & + \\
\hline Galactitol & - & - & - & - & - \\
\hline Ribitol & - & - & - & - & + \\
\hline Palatinose & + & + & + & + & - \\
\hline Glycerol & + & + & + & + & + \\
\hline Glucitol & - & - & - & - & + \\
\hline Meso-Erithritol & - & - & - & - & - \\
\hline Melibiosi & - & - & - & - & - \\
\hline Cycloheximide & - & - & - & - & + \\
\hline Myo-Inositol & - & - & - & - & - \\
\hline Potassium Nitrate & - & - & - & - & + \\
\hline 2-K-Gluconate & - & - & - & - & + \\
\hline
\end{tabular}

(-)Negative test, (+) Positive test in the analyzed cultures. The capacity to synthesize all the necessary vitamins for their growth was a common characteristic among the isolated biotypes, which showed growth in a medium free of vitamins. Carbon assimilation is an important criterion in the taxonomy and identification of yeasts, which depends on organic carbon sources for their energy supply and growth, the carbohydrates being the sources of greater importance. Sugars such as glucose, fructose, mannose are assimilated by all studied species $(3,10)$, while some oligosaccharides, polysaccharides, alcohols, organic acids, among others, used only by some species of yeasts (15). Yeasts are also capable of using different nitrogen sources; however, assimilation from nitrate, nitrites and amino acids is specific for some species $(14,19)$. The L12, L108, L135 and L137 strains presented physiological, biochemical and morphological characteristics that fit the standard description of Rhodotorula mucilaginosa species. They differed in their ability to assimilate carbohydrates. The L12, L108 and L135 strains did not assimilate trehalose, both trehalose and xylitol, and xylitol, respectively, while the L137 strain assimilated these two carbohydrates. The L125 strain assimilated trehalose and xylitol, and was identified as Rhodotorula graminis. This strain showed growth in the presence of cycloheximide, while the others had negative growth. The isolated $R$. mucilaginosa had weak growth at $37^{\circ} \mathrm{C}$, while Rhodotorula graminis did not grow at this temperature.

The pigmented yeasts of the genera Rhodotorula, Rhodosporidium, Sporobolomyces have the capacity to produce carotenoids. Their carotenoid composition is similar, consisting of $\beta$ carotene, $\gamma$-carotene, torulene and torularhodin $(5,18)$. Fig. 1-A shows the spectrum of an extract obtained from a strain of R. mucilaginosa-108 yeast, with maximum absorptions at 455,482 and $513 \mathrm{~nm}$ in petroleum ether. The spectra of the other strains of $R$. mucilaginosa had similar profiles. Fig. 1-B presents the spectrum of the extract obtained from $R$. graminis, with maximum absorptions at 453, 479 and $512 \mathrm{~nm}$ in petroleum ether. Both spectra are typical of a mixture of carotenoids. The difference in shape indicates a difference in carotenoid composition. The HPLC chromatogram of $R$. mucilaginosa (Figure 2), along with the visible absorption spectra obtained with the photodiode array detector, show torulene as the major carotenoid, followed by $\beta$-carotene. On the other haad the HPLC chromatogram of $R$. graminis 


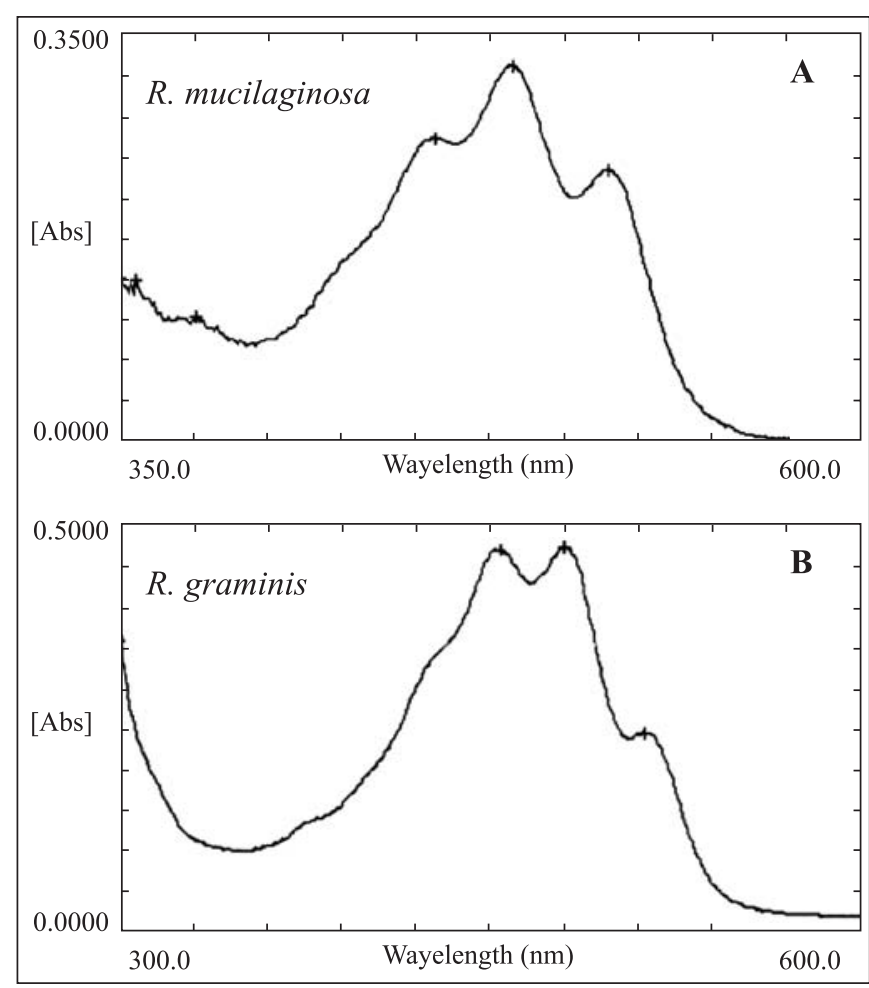

Figure 1. Spectra in petroleum ether of the total carotenoid extract obtained from: A- $R$. mucilaginosa, with $\operatorname{lmax}$ at 455,482 and $513 \mathrm{~nm} ; \mathbf{B}-R$. graminis, with $\lambda$ max at 453, 479 and $512 \mathrm{~nm}$.

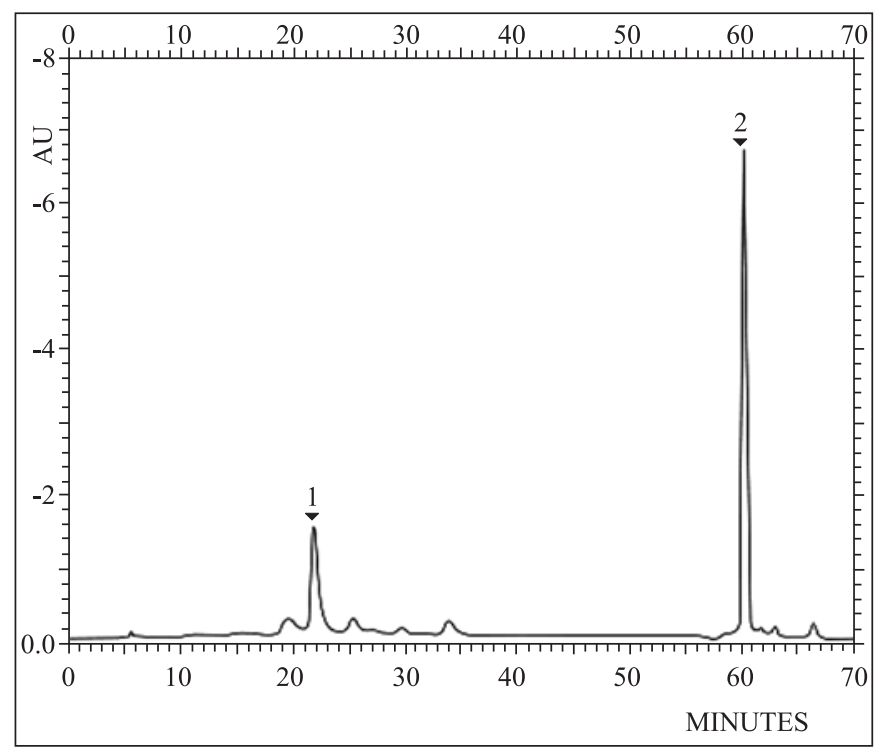

Figure 2. Typical HPLC chromatogram of the carotenoids from R. mucilaginosa-12, R. mucilaginosa-108, R. mucilaginosa-135 and $R$. mucilaginosa-137 strains. HPLC conditions are described in the text. Detection was at $450 \mathrm{~nm}$. Peak identification: 1 . $\beta$ carotene and 2. torulene.
(Figure 3) and the visible absorption spectra present $\beta$-carotene as the main carotenoid, followed by torulene. Torulene is a typical carotenoid found in yeasts with a nice reddish colour. Its structure has 13 bonds with a $\beta$-ring without substituents and a lateral polyene chain of 11 carbons, having requirement for provitamin A activity and also the antioxidant activity higher than others carotenoids (21). Since the pigment production by fermentation depends on culture conditions and the genus of microorganism, the process can be managed to produce mainly torulene.

Table 2 shows that $R$. mucilaginosa-137 (8.7 $\mathrm{g} / \mathrm{l})$ had highest biomass production, while $R$. mucilaginosa-12 had the least $(6.7 \mathrm{~g} / \mathrm{l})$. The total carotenoid concentration has not had a significant difference among the identified strains, while $R$. mucilaginosa-135 presented the highest value $(61.4 \mu \mathrm{g} / \mathrm{g}), R$. mucilaginosa-137 presented the lowest value $(54.7 \mu \mathrm{g} / \mathrm{g})$. Perrier

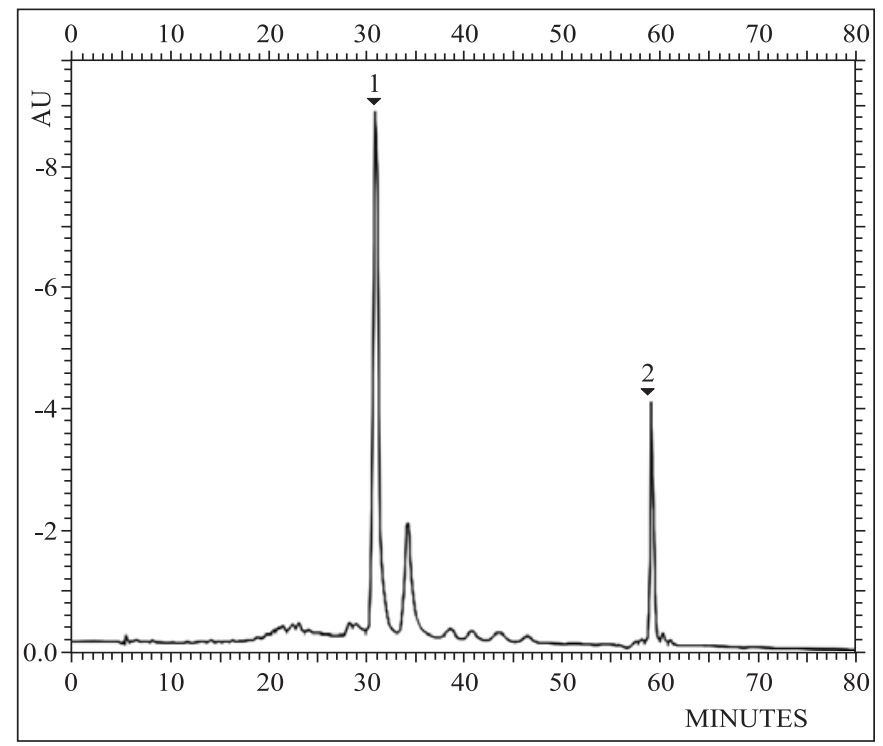

Figure 3. Typical HPLC chromatogram of the carotenoids from R. graminis. HPLC conditions are described in the text. Detection was at $450 \mathrm{~nm}$. Peak identification: 1 . $\beta$-carotene, 2 . torulene.

Table 2. Fermentation parameters obtained after 5 days of cultivation in YM medium broth.

\begin{tabular}{lccc}
\hline Yeast strain & $\begin{array}{c}\text { Dry biomass } \\
(\mathrm{g} / \mathrm{l})\end{array}$ & $\begin{array}{c}\text { pH } \\
(\mathrm{mg} / \mathrm{g})\end{array}$ \\
\hline Rhodotorula mucilaginosa-12 & 6.7 & 5.7 & 58.1 \\
Rhodotorula mucilaginosa-108 & 8.2 & 6.2 & 54.8 \\
Rhodotorula mucilaginosa-135 & 7.1 & 6.1 & 61.4 \\
Rhodotorula mucilaginosa-137 & 8.7 & 6.2 & 54.7 \\
Rhodotorula graminis-125 & 8.5 & 6.3 & 55.9 \\
\hline
\end{tabular}


et al. (13) determined the total carotenoid from Rhodotorula $\mathrm{sp}$, and observed that the concentrations varied from $10 \mu \mathrm{g} / \mathrm{g}$ to $100 \mu \mathrm{g} / \mathrm{g}$. Shih and Hang (17) also obtained total carotenoids of Rhodotorula sp, expressed as $\beta$-carotene, at a range from 52.2 to $131 \mu \mathrm{g} / \mathrm{g}$. The total carotenoid content varies widely in the Rhodotorula sp. According to Aksu and Tugba Eren (1), Rhodotorula mucilaginosa will be one of the most promising microorganisms for the commercial production of carotenoids, by optimizing the culture conditions.

In this present work, $\beta$-carotene predominated in Rhodotorula graminis-125, while torulene was the major carotenoid in Rhodotorula mucilaginosa. The total carotenoid concentration found in the wild strains is in accordance with those shown in the literature. Therefore, the wild yeasts selected, characterized and identified have potential as microbial sources for producing carotenoids by fermentation. Moreover, their carotenoid concentration and composition can be maximized by changing the parameters of the biotechnological process. The optimization of fermentation process to produce carotenoids by response surface methodology is reported in a separate paper.

\section{RESUMO}

\section{Seleção e caracterização de leveduras produtoras decarotenóides na região de Campinas, Brasil}

Este trabalho teve como objetivo selecionar e identificar leveduras encontradas no Brasil capazes de produzir carotenóides. As leveduras pigmentadas foram isoladas de amostras de solos, folhas, frutos, flores e um alimento processado. As amostras foram colocadas em frascos de erlenmeyer, contendo meio de Extrato de Malte e Levedura (YM), e incubadas a $30^{\circ} \mathrm{C}$. Após 48 horas, as amostras foram inoculadas em placas de petri contendo meio YM ágar e incubadas a $30^{\circ} \mathrm{C}$ por 120 horas. As colônias, que apresentaram coloração entre amarelo e vermelho, foram transferidas para os tubos de culturas, contendo meio YM ágar e incubadas a $30^{\circ} \mathrm{C}$ por 72 horas. Das 242 amostras, somente cinco delas apresentaram coloração intensa entre amarelo e vermelho. Estas colônias de leveduras foram reisoladas, em placas de petri contendo YM ágar e, posteriormente, transferidas para tubos de ensaios contendo GPYM ágar. A identificação das leveduras, baseada nas características morfológicas, de reprodução, além dos testes fisiológicos e bioquímicos, classificou quatro linhagens como Rhodotorula mucilaginosa e uma como Rhodotorula graminis. Os principais pigmentos extraídos destas linhagens foram identificados através da análise de cromatografia de alta eficiência como $\beta$-caroteno e toruleno. As linhagens de leveduras mostraram potencial como microrganismos promissores para a produção comercial de carotenóides por fermentação.

Palavras-chave: Carotenóide, identificação, levedura, Rhodotorula, fermentação

\section{REFERENCES}

1. Aksu, Z.; Tugba Eren, A. (2005). Carotenoid production by the yeast Rhodotorula mucilaginosa: Use of agricultural wastes as carbon source. Process biochem., 40, 2985-2991.

2. Astorg, P. Food carotenoids and cancer prevention (1997). An overview of current research. Trends Food Sci. Technol., 8, 406-413.

3. Barnett, J.A.; Payne, R.W.; Yarrow, D. (1990). Yeasts: Characteristics and Identification. Cambridge University Press, Cambridge, 1002p.

4. Bendich, A. (1994). Recent advances in clinical research involving carotenoids. Pure Appl. Chem., 66, 1017-1024.

5. Costa, I.; Martelli da Silva (1987). Production of b-carotene by Rhodotorula strain. Biotech. Letters, 9, 373-375.

6. Johnson, E.A.; Conklin, D.E.; Lewis, M.J. (1979). Astaxanthin formation by yeast Phaffia rhodozyma. J. Gen. Microbiol., 115, 173-183.

7. Johnson, E.A.; Schroeder, W.A. (1995). Microbial carotenoids. Adv. Bioch. Eng. Biotech., 11, 297-326.

8. Kreger-Van Rij, N.J.W. (1984). General classification of the yeasts. In: KREGER-VAN RIJ, N.J.W. (Ed). The yeasts: a Taxonomy Study. Elsevier Science, Amsterdam, 1-44p.

9. Krinsky, N.I. (2001). Carotenoid antioxidants. Nutr., 17, 815-817.

10. Kurtzman, C.P.; Fell, J.W. (1998). The Yeast: a Taxonomic Study. Elsevier, $4^{\text {th }}$ edition, $1955 \mathrm{p}$.

11. Lodder, J. (1970). The yeasts: a Taxonomic Study. North-Holland, London, 1385p.

12. Nelis, H.J.; De Leenheer, A.P. (1991). Microbial sources of carotenoids pigments used in foods and feeds. J. of Appl. Bacteriol., 70, 181-191.

13. Perrier, V.; Dubreucq, E.; Gayzy, P. (1995). Fatty acid and carotenoid composition of Rhodotorula strains. Arch. Microbiol., 164, 173-179.

14. Phaff, H.J.; Miller, M.W.; Mirak, E.M. (1978). The Life of the Yeasts. Harvard University Press, Massachusetts, 341p.

15. Phaff, H.J. (1990). Isolation of yeasts from natural sources. In: LACERDA, D.P. (ED). Isolation of Biotechnology Organisms from Nature. McGraw-Hill, New York, 53-79p.

16. Rodriguez-Amaya, B.D. (1999). A Guide to Carotenoids Analysis in Foods. Washington, D.C.: International Life Science Institute, 64p.

17. Shih, C.T.; Hang, Y.D. (1996). Production of carotenoids by Rhodotorula rubra from Sauerkraut brine. Lebensm. Wiss. U.Technol., 29, 570-572.

18. Simpson, K.L.; Chichester, C.O.; Phaff, H.J. (1971). Carotenoid pigments of yeast. In: Rose, A.H.; Harrison, J.S. (Ed.). The Yeasts, Vol. 2., Academic Press, New York, 493-515p.

19. Souza, L.C. (1969). Distribution of yeast in nature. In: ROSE, A. H.; HARRISON, J.S. (Ed). The yeasts: Biology of the Yeasts. Academic Press, London, v.1, 79-106p.

20. Spencer, J.F.T.; Spencer, D.M. (1997). Yeasts in Natural and Artificial Habitats. Springer, 381p.

21. Terão, J. (1989). Antioxidant activity of $\beta$-carotene-related carotenoids in solution. Lipids, 24, 659-661. 